\title{
Evaluation of Different Varieties of Aerobic Rice (Oryza sativa L.) under Different Fertigation Levels on Growth and Yield Parameters
}

\author{
M. Chandrika*, M. Uma Devi, V. Ramulu and M. Venkata Ramana \\ Water Technology Centre, College of Agriculture, Professor Jayashankar Telangana State \\ Agricultural University, Rajendranagar, Hyderabad - 500 030, India \\ *Corresponding author:
}

\begin{tabular}{|c|c|}
\hline & A B S T R A C T \\
\hline & \multirow{6}{*}{$\begin{array}{l}\text { A field experiment was conducted at Water Technology Centre, College farm, } \\
\text { Rajendranagar, Hyderabad during kharif, } 2015 \text { to study the "Response of different } \\
\text { varieties of aerobic rice (Oryza sativa l.) under drip fertigation levels." The experiment } \\
\text { was conducted with three main treatments and four sub treatments. The main treatments } \\
\text { were three rice varieties (RNR } 15048 \text {, MTU } 1010 \text { and Anagha) and the sub treatments } \\
\text { were four different fertigation levels }\left(\mathrm{S}_{0} \text { : Control, } \mathrm{S}_{75}: 90-45-30 \mathrm{~kg} \mathrm{~N}-\mathrm{P}_{2} \mathrm{O}_{5}-\mathrm{K}_{2} \mathrm{O} \mathrm{ha}^{-1} \text {, }\right. \\
\mathrm{S}_{100}: 120-60-40 \mathrm{~kg} \mathrm{~N}-\mathrm{P}_{2} \mathrm{O}_{5}-\mathrm{K}_{2} \mathrm{O} \text { ha }{ }^{-1}, \mathrm{~S}_{125}: 150-75-50-\mathrm{N}-\mathrm{P}_{2} \mathrm{O}_{5}-\mathrm{K}_{2} \mathrm{O} \text { ha }{ }^{-1} \text {. Drip irrigation was } \\
\text { scheduled once in } 3 \text { days based on daily data of USWB class 'A' pan evaporimeter at } 1.5 \\
\text { Epan. The amount of total irrigation water used including effective rain fall }(277 \mathrm{~mm}) \text { for } \\
\text { different varieties were Anagha }\left(9720 \mathrm{~m}^{3}\right) \text {, MTU } 1010\left(9910 \mathrm{~m}^{3}\right) \text { and RNR } 15048(10110 \\
\left.\mathrm{m}^{3}\right) \text { through drip irrigation. The differences in amount of water used were different for } \\
\text { different varieties due to the differences in their crop growth period. The crop growth } \\
\text { period noticed was } 131,139 \text { and } 151 \text { days for Anagha, MTU } 1010 \text { and RNR } 15048 \\
\text { respectively. The data on grain yield, straw yield, growth parameters, dry matter } \\
\text { production, were recorded at different growth stages. }\end{array}$} \\
\hline & \\
\hline $\begin{array}{l}\text { Aerobic rice, Drip } \\
\text { fertigation, Pan } \\
\text { evaporimeter, } \\
\text { Effective rainfall }\end{array}$ & \\
\hline Artic & \\
\hline $\begin{array}{l}\text { Accepted: } \\
26 \text { April } 2017 \\
\text { Available Online: } \\
11 \text { May } 2017\end{array}$ & \\
\hline & \\
\hline
\end{tabular}

\section{Introduction}

Rice (Oryza sativa L.) is one of the most important staple food crop in the world. Rice is the staple food in Asia but also the single biggest "user" of fresh water. The declining availability of water threatens the traditional way of irrigated rice production. Further, Asia is considered to be "RICE BOWL" of the world and produces more calories and carbohydrates per hectare than any other cereals in India (Lu and Chang, 1980). An efficient use of water is essential to safeguard food security in Asia. Technologies like saturated soil culture and alternate wetting and drying are found promising but require prolonged periods of flooding. Aerobic rice, reduce water inputs in rice field by cutting down the unproductive water losses caused due to seepage and percolation.

Experiments on aerobic rice have shown that water inputs were more than 50 per cent lesser (only 470-650 $\mathrm{mm}$ ) and water productivities were 64-88 per cent higher than the lowland rice, but require improved varieties bred specifically for aerobic condition. 


\section{Materials and Methods}

A field experiment was conducted at Water Technology Centre, College farm, Rajendranagar, Hyderabad during kharif, 2015 to study the response of different varieties of aerobic rice (Oryza sativa l.) under drip fertigation levels. The experiment was conducted with three main treatments and four sub treatments. The main treatments were three rice varieties (RNR 15048, MTU 1010 and Anagha) and the sub treatments were four different fertigation levels $\left(\mathrm{S}_{0}\right.$ : Control, $\mathrm{S}_{75}: 90-45-30 \mathrm{~kg} \mathrm{~N}-\mathrm{P}_{2} \mathrm{O}_{5}-\mathrm{K}_{2} \mathrm{O} \mathrm{ha}^{-1}$, $\mathrm{S}_{100}: 120-60-40 \mathrm{~kg} \mathrm{~N}-\mathrm{P}_{2} \mathrm{O}_{5}-\mathrm{K}_{2} \mathrm{Oha}^{-1}, \mathrm{~S}_{125}: 150-$ 75-50- N-P $\mathrm{P}_{2}-\mathrm{O}_{2} \mathrm{O}$ ha ${ }^{-1}$ ).

The experimental soil was sandy clay loam in texture, slightly alkaline in reaction, nonsaline, low in organic carbon and available nitrogen, medium in available phosphorous and high in available potassium.

The mean weekly maximum (RH-II) and minimum relative humidity (RH-I during the crop growing period varied from) 73 to 95.28 $\%$ and 39.5 to $75.42 \%$ respectively, during kharif, 2015 and $369.9 \mathrm{~mm}$ of rainfall was received in 26 rainy days. The mean bright sunshine hours per day varied from 1.77 to 8.25. The average wind speed varied from 0.1 to $11.34 \mathrm{~km} \mathrm{~h}^{-1}$ in 2015 . With respect to pan evaporation, mean pan evaporation ranged 2.7 to $7.98 \mathrm{~mm} \mathrm{day}^{-1}$ in 2015 . The seasonal cumulative pan evaporation during the crop period of kharif, 2015 was $687.6 \mathrm{~mm}$.

Out of the varieties chosen, RNR 15048 is recently released by P.J.T.S.A.U. as Telangana Sona and is gaining wider popularity among farming community. Hence there is a need to generate the data on this new variety in different management practices. Hence this variety was included. The other variety MTU 1010 is a widely accepted, cold tolerant, bold seeded variety in both Telangana and Andhra Pradesh state and was found to perform better under aerobic conditions than other popular varieties. Hence this variety was included under the study. The third variety Anagha is a variety specially released for growing under aerobic conditions by U.A.S, Bangalore. To test its suitability under Telangana, this variety was also included under the present study. The data grain yield and straw yield were collected and water productivity was computed.

\section{Results and Discussion}

Data on growth parameters like plant height, no. of tillers $\mathrm{m}^{-2}$, days to $50 \%$ flowering and dry matter production are presented in Table 1, Table 2, Table 3 and Table 4. It is significantly influenced by the varieties, fertigation levels but not by their interaction.

The plant height of aerobic rice ranged from 18.9 to $28.7 \mathrm{~cm}, 38.5$ to $53.1 \mathrm{~cm}, 56.5$ to 78.1 $\mathrm{cm}$ and $76.6 \mathrm{~cm}$ to $103.8 \mathrm{~cm}$ in $30,60,90$ DAS and at harvest respectively. Among all varieties, Anagha has recorded significantly, the highest plant height at all stages except 30 DAS followed by RNR 15048 and MTU 1010. The $S_{125}$ has recorded the highest plant height at all the growth stages studied followed by $S_{75}, S_{100}$ and $S_{0}$ respectively. Among the interactions, Anagha at $S_{125}$ has recorded the highest plant height followed by Anagha at $S_{100}$ in all the stages except at 30 DAS. Significantly, the lowest plant height has recorded in MTU 1010 at $\mathbf{S}_{0}$.

Plant height is a function of genetic as well as environmental conditions (Abid Khan et al., 2014). Increased levels of irrigation regime through drip system with fertigation favoured plant height positively were reported by Govindan and Myrtel Grace (2012).

The no. of tillers $\mathrm{m}^{-2}$ ranged from 186 to 272 , 191 to 290,204 to 300 and 171 to 257 at 30 , 
60, 90 DAS and at harvest respectively. There was a constant increase in the no. of tillers $\mathrm{m}^{-}$ ${ }^{2}$ up to 90 DAS, but afterwards reduction was noticed by final harvest due to mortality of some tillers. Anagha at $\mathrm{S}_{125}$ has recorded significantly the highest no. of tillers $\mathrm{m}^{-2}$ followed by the same variety at $S_{100}$ at all the stages. Significantly the lowest no. of tillers $\mathrm{m}^{-2}$ was recorded in MTU 1010 at $\mathrm{S}_{0}$ in all the stages except at 30 DAS. The $\mathrm{S}_{75}, \mathrm{~S}_{100}$ and $\mathrm{S}_{100}$ have recorded $9.18 \%, 14.28 \%, 17.85 \%$ higher no. of tillers $\mathrm{m}^{-2}$ respectively over $\mathrm{S}_{0}$.

Relatively lower number of tillers under aerobic cultivation, when compared to transplanted rice was reported by Patel et al., (2010). Greater tiller mortality as a result of water deficit and iron deficiency might be the reason for lower tiller number in case of the aerobic rice. Higher number of tillers with $\mathrm{N}_{180} \mathrm{P}_{90} \mathrm{~K}_{60}+\mathrm{FeSO}_{4}$ was reported by Rakesh et al., (2012). Bouman and Tuong (2001) stated that when rice is subjected to moisture stress, leads to lower no. of tillering. Similar results were expressed by Govindan and Myrtle Grace (2012).

The leaf area index (LAI) ranged from 0.57 to $0.82,2.07$ to $3.89,3.79$ to 4.23 and 3.69 to 4.11 at $30,60,90$ DAS and at harvest respectively. Among all the varieties, Anagha recorded significantly the highest leaf area index followed by MTU 1010 and RNR 15048 at all the stages except at 60 DAS. The $\mathrm{S}_{125}$ recorded significantly, the highest leaf area index followed by $S_{100}, S_{75}$ and $S_{0}$ at all the stages. The $\mathrm{S}_{75}, \mathrm{~S}_{100}$ and $\mathrm{S}_{125}$ have recorded 1.06, 5.10 and 7.80 per cent higher LAI over control $\left(S_{0}\right)$. Anagha at $S_{125}$ has recorded significantly, the highest leaf area index at all the stages. A larger leaf area in relation to the mass of the leaves means a higher specific leaf area, and to support this relative increase in leaf area it requires a greater investment in the stem (De Groot et al., 2002). Availability of both water and nutrients throughout the growth period of crop in fertigated treatments have helped in higher LAI.

Among varieties, Anagha attained 50\% flowering (86 days) earlier when compared to MTU 1010 (93 days) and RNR 15048 (105 days). When compared to Anagha, the remaining two varieties MTU 1010 and RNR 15048 took 7 and 19 days late to attain $50 \%$ flowering respectively. As the RNR 15048 has semi photo sensitivity, that could be the reason for its delay to come to $50 \%$ flowering than the other two varieties.

Among varieties, Anagha attained 50\% flowering (86 days) earlier when compared to MTU 1010 (93 days) and RNR 15048 (105 days). When compared to Anagha, the remaining two varieties MTU 1010 and RNR 15048 took 7 and 19 days late to attain 50\% flowering respectively. As the RNR 15048 has semi photo sensitivity, that could be the reason for its delay to come to $50 \%$ flowering than the other two varieties. There was no significant difference found among NPK fertigation levels and interactions.

The dry matter production ranged from 198 to 347, 1948 to 4815,2215 to 5495 and 3611 to $8956 \mathrm{~kg} \mathrm{ha}^{-1}$ at 30, 60, 90 and final harvest respectively. Anagha recorded significantly the highest dry matter production followed by MTU 1010 and RNR 15048 respectively at all the stages except at 30 DAS. Anagha recorded $48.02 \%$ and $55.89 \%$ higher dry matter production than RNR 15048 and MTU 1010 respectively. Among the NPK fertigation levels, $S_{125}$ has recorded the highest dry matter production followed by $\mathrm{S}_{100}, \mathrm{~S}_{75}$ and $\mathrm{S}_{0}$ respectively.

The $S_{75}, S_{100}$ and $S_{125}$ have recorded 20.5, 40.9 and 65.5 per cent higher dry matter production over control $\left(\mathrm{S}_{0}\right)$. Anagha at $\mathrm{S}_{125}$ has recorded significantly the highest dry 
matter production followed by Anagha at $S_{100}$ at all the stages. The lowest dry matter production was recorded in RNR 15048 at $\mathrm{S}_{0}$ at all the stages except at 30 DAS. Increased dry matter production with increase in NPK levels up to $180-90-60 \mathrm{~kg} \mathrm{~N}-\mathrm{P}_{2} \mathrm{O}_{5}$ and $\mathrm{K}_{2} \mathrm{O}$ along with iron sulphate application was reported by Rakesh et al., (2012). Ramamoorthy et al., (1998) observed increased yield attributes leading to higher dry matter production as a result of frequent irrigations. Increase in dry matter production with increase in $\mathrm{N}$ level was also reported by Kumar et al., (1996) and they concluded that when rice is grown under aerobic condition, the inability of roots to acclimatise to such changes in soil water regimes may result in reduced growth and function thereby, dry matter production when compared to flooded conditions.

Data on grain yield, straw yield are presented in Table 5. The grain yield ranged from 1103 to $2578 \mathrm{~kg} \mathrm{ha}^{-1}$. Among all varieties, Anagha recorded significantly the highest grain yield followed by MTU 1010 and RNR 15048. The varieties MTU 1010 and RNR 15048 were observed to be on par to each other. Anagha, recorded $38.75 \%$ and $46.10 \%$ higher grain yield than MTU 1010 and RNR 15048 respectively.

Among the NPK fertigation levels, $\mathrm{S}_{125}$ recorded significantly the highest grain yield followed by $S_{100}, S_{75}$ and $S_{0}$ respectively. The $\mathrm{S}_{75}, \mathrm{~S}_{100}$ and $\mathrm{S}_{125}$ have recorded $21.6 \%, 39.8$ $\%$ and $60.4 \%$ higher grain yield over control $\left(\mathrm{S}_{0}\right)$.Among interactions, higher grain yield was recorded by Anagha at $S_{125}$ followed by the same variety at $S_{100,}$ at $S_{75}$ and MTU 1010 at $\mathrm{S}_{125}$. The lowest was recorded by RNR 15048 at $S_{0}$ which was on par with MTU at $\mathrm{S}_{0 .} \quad$ It was noticed that under aerobic cultivation, among the varieties tested, Anagha was observed to perform better over other two varieties. As it is the variety specially released for aerobic cultivation, it could adopt to aerobic conditions better than the other two varieties. Katsura and Nakaide (2011) found that the varieties with greater sink activity and source capacity per plant during the ripening period could produce larger grain weight under aerobic culture.

The straw yield ranged from 2501 to $6378 \mathrm{~kg}$ $\mathrm{ha}^{-1}$. Among all varieties, Anagha recorded significantly higher grain yield followed by MTU 1010 and RNR 15048. Anagha, recorded $51.88 \%$ and $60.22 \%$ higher straw yield than MTU 1010 and RNR 15048 respectively. Among the NPK fertigation levels, $S_{125}$ has recorded significantly the highest straw yield followed by $S_{100}, S_{75}$ and $\mathrm{S}_{0}$ respectively. The $\mathrm{S}_{75}, \mathrm{~S}_{100}$ and $\mathrm{S}_{125}$ have recorded $19.9 \%, 41.7 \%$ and $67.8 \%$ higher straw yield over control $\left(\mathrm{S}_{0}\right)$. Among the interactions, significantly the highest straw yield was observed by Anagha at $S_{125}$ followed by the same variety at $S_{100}$.The lowest was recorded by MTU at $\mathrm{S}_{0}$ which was on par with RNR 15048 at $\mathrm{S}_{0}$. Increase in straw yield with increase in NPK / N fertilizer doses was also reported by Rakesh et al., (2012) and Malla Reddy et al., (2012).

Thus based on the growth parameters, yield attributes, nutrient uptakes and soil fertility at crop harvest, it can be recommended to go for fertigation of NPK up to $125 \%$ level (150$75-50 \mathrm{~kg} \mathrm{~N}-\mathrm{P}_{2} \mathrm{O}_{5}-\mathrm{K}_{2} \mathrm{O}$ ha $^{-1}$ ), applied in ten splits at weekly interval to aerobic rice from emergence to flowering stage. Among the varieties tested, Anagha was found to be more suitable for aerobic rice cultivation followed by MTU 1010 and RNR 15048 . 
Table.1 Effect of different levels of NPK fertigation levels on plant height $(\mathrm{cm})$ of different varieties of rice at 30,60, $90 \mathrm{DAS}$ and at final harvest under aerobic during kharif, 2015. 30

DAS

\begin{tabular}{|c|c|c|c|c|c|}
\hline \multirow[t]{2}{*}{ Varieties } & \multicolumn{4}{|c|}{ Fertigation levels* } & \multirow[t]{2}{*}{ Mean } \\
\hline & $\mathrm{S}_{0}$ & $\mathrm{~S}_{75}$ & $\mathrm{~S}_{100}$ & $\mathrm{~S}_{125}$ & \\
\hline RNR 15048 & 22.2 & 26.1 & 28.2 & 28.7 & 26.3 \\
\hline MTU 1010 & 18.9 & 20.3 & 22.3 & 22.5 & 21.2 \\
\hline Anangha & 23.7 & 24.8 & 25.4 & 26.1 & 25.1 \\
\hline Mean & 21.6 & 23.8 & 23.1 & 25.8 & \\
\hline & Main $(\mathrm{V})^{* *}$ & Sub (S) & V at same $\mathrm{S}$ & $\mathrm{S}$ at same v & \\
\hline $\mathrm{SE}+/-$ & 0.5 & 0.3 & 0.5 & 0.6 & \\
\hline $\mathrm{CD}(\mathrm{P}=0.05)$ & 1.8 & 0.9 & 1.1 & 1.5 & \\
\hline \multicolumn{6}{|c|}{60 DAS } \\
\hline RNR 15048 & 42.9 & 46.1 & 41.5 & 45.1 & 43.9 \\
\hline MTU 1010 & 38.5 & 39.9 & 41.8 & 41.6 & 40.5 \\
\hline Anangha & 49.6 & 48.9 & 49.9 & 53.1 & 50.4 \\
\hline Mean & 43.7 & 44.9 & 44.0 & 46.6 & \\
\hline & Main $(\mathrm{V})$ & Sub (S) & V at same $\mathrm{S}$ & S at same V & \\
\hline $\mathrm{SE}+/-$ & 0.37 & 0.44 & 0.71 & 0.74 & \\
\hline $\mathrm{CD}(\mathrm{P}=0.05)$ & 1.43 & 1.29 & 1.56 & 1.7 & \\
\hline \multicolumn{6}{|c|}{90 DAS } \\
\hline RNR 15048 & 62.9 & 63.6 & 63.7 & 66.4 & 64.2 \\
\hline MTU 1010 & 56.5 & 60.8 & 60.6 & 64.7 & 60.7 \\
\hline Anangha & 70.8 & 73.1 & 76.2 & 78.1 & 74.5 \\
\hline Mean & 63.4 & 65.9 & 66.9 & 69.8 & \\
\hline & Main $(\mathrm{V})$ & Sub (S) & V at same $S$ & $\mathrm{~S}$ at same V & \\
\hline $\mathrm{SE}+/-$ & 1.1 & 1.0 & 1.7 & 1.8 & \\
\hline $\mathrm{CD}(\mathrm{P}=0.05)$ & 4.2 & 2.9 & NS & NS & \\
\hline \multicolumn{6}{|c|}{ At final harvest } \\
\hline RNR 15048 & 86.7 & 87.6 & 85.1 & 89.4 & 87.2 \\
\hline MTU 1010 & 76.6 & 79.1 & 82.7 & 87.6 & 81.5 \\
\hline Anangha & 93.4 & 95.9 & 99.3 & 103.8 & 98.1 \\
\hline \multirow[t]{2}{*}{ Mean } & 85.6 & 87.6 & 89.1 & 93.6 & \\
\hline & Main (V) & Sub (S) & $\mathrm{VxS}$ & SXV & \\
\hline $\mathrm{SE}+/-$ & 1.0 & 1.2 & 2.0 & 1.9 & \\
\hline $\mathrm{CD}(\mathrm{P}=0.05)$ & 3.8 & 3.5 & NS & $\mathrm{NS}$ & \\
\hline
\end{tabular}


Table.2 Effect of different levels of NPK fertigation levels on no. of tillers m-2 of different varieties of rice at 30,60, 90 DAS and at final harvest under aerobic cultivation duringkharif, 2015

30 DAS

\begin{tabular}{|c|c|c|c|c|c|}
\hline Varieties & \multicolumn{4}{|c|}{ Fertigation levels* } & \multirow[t]{2}{*}{ Mean } \\
\hline & $\mathrm{S}_{0}$ & $\mathrm{~S}_{75}$ & $S_{100}$ & $\mathrm{~S}_{125}$ & \\
\hline RNR 15048 & 186 & 202 & 204 & 218 & 203 \\
\hline MTU 1010 & 197 & 219 & 230 & 245 & 223 \\
\hline Anangha & 221 & 249 & 244 & 272 & 247 \\
\hline \multirow[t]{2}{*}{ Mean } & 202 & 224 & 226 & 245 & \\
\hline & $\operatorname{Main}(\mathrm{V})^{* *}$ & Sub (S) & $\mathrm{V}$ at same $\mathrm{S}$ & S at same V & \\
\hline $\mathrm{SE}+/-$ & 6 & 3 & 4 & 6 & \\
\hline $\mathrm{CD}(\mathrm{P}=0.05)$ & 23 & 8 & 9 & 18 & \\
\hline
\end{tabular}

\begin{tabular}{|l|c|c|c|c|c|}
\hline RNR 15048 & 196 & 214 & 225 & 242 & $\mathbf{2 2 0}$ \\
\hline MTU 1010 & 199 & 219 & 238 & 243 & $\mathbf{2 2 3}$ \\
\hline Anangha & 237 & 253 & 265 & 290 & $\mathbf{2 6 2}$ \\
\hline & & & & 259 & \\
\hline Mean & $\mathbf{2 0 8}$ & $\mathbf{2 2 9}$ & $\mathbf{2 4 3}$ & $\mathbf{2 5 9}$ \\
\hline SE+/- & $3 a i n(V)$ & Sub (S) & V at same V & S at same V \\
\hline CD $(\mathrm{P}=0.05)$ & 12 & 3 & 4 & 7 \\
\end{tabular}

\begin{tabular}{|c|c|c|c|c|c|}
\hline \multicolumn{6}{|c|}{90 DAS } \\
\hline RNR 15048 & 204 & 218 & 234 & 252 & 227 \\
\hline MTU 1010 & 226 & 252 & 255 & 249 & 246 \\
\hline Anangha & 249 & 263 & 273 & 300 & 271 \\
\hline Mean & 227 & 245 & 254 & 267 & \\
\hline & Main (V) & Sub (S) & $\mathrm{V}$ at same $\mathrm{S}$ & S at same V & \\
\hline $\mathrm{SE}+/-$ & 3 & 3 & 5 & 5 & \\
\hline $\mathrm{CD}(\mathrm{P}=0.05)$ & 10 & 8 & 10 & 11 & \\
\hline
\end{tabular}

\begin{tabular}{|l|c|c|c|c|c|}
\hline \multicolumn{5}{|c|}{ At final harvest } & 222 \\
\hline RNR 15048 & 173 & 187 & 204 & 219 & $\mathbf{2 1 5}$ \\
\hline MTU 1010 & 197 & 222 & 224 & 252 & $\mathbf{2 3 8}$ \\
\hline Anangha & 219 & 235 & 244 & & \\
\hline Mean & & & & $\mathbf{2 3 1}$ \\
\hline SE+/- & Main (V) & Sub (S) & V at same S & S at same V \\
\hline CD $(\mathrm{P}=0.05)$ & 1 & 1 & 2 & 2 \\
\hline
\end{tabular}

$* \mathrm{~S}_{0}=$ Control $\left(\mathrm{No} \mathrm{N}, \mathrm{P}_{2} \mathrm{O}_{5}, \mathrm{~K}_{2} \mathrm{O}\right), \mathrm{S}_{75}=90-45-30 \mathrm{~kg} \mathrm{~N}, \mathrm{P}_{2} \mathrm{O}_{5}, \mathrm{~K}_{2} \mathrm{O}$ ha $^{-1}$,

$\mathrm{S}_{100}=120-60-40 \mathrm{~kg} \mathrm{~N}, \mathrm{P}_{2} \mathrm{O}_{5}, \mathrm{~K}_{2} \mathrm{O}$ ha-1, $\mathrm{S}_{125}=150-75-50 \mathrm{~kg} \mathrm{~N}, \mathrm{P}_{2} \mathrm{O}_{5}, \mathrm{~K}_{2} \mathrm{O}$ ha ${ }^{-1}$

** Main $(\mathrm{V})=$ Main treatments (Rice varieties); Sub $(\mathrm{F})=$ Sub treatments ( Fertigation levels)

Interactions $=$ Main treatments $\mathrm{x}$ Sub treatments (Rice varieties $\mathrm{x}$ fertigation levels) 
Table.3 Effect of different levels of NPK fertigation levels on leaf area index of different varieties of rice at 30,60,90 DAS and at final harvest under aerobic cultivation duringkharif, 2015

\begin{tabular}{|c|c|c|c|c|c|}
\hline Varieties & \multicolumn{4}{|c|}{ Fertigation levels* } & \multirow[t]{2}{*}{ Mean } \\
\hline & $\mathrm{S}_{0}$ & $\mathrm{~S}_{75}$ & $S_{100}$ & $S_{125}$ & \\
\hline RNR 15048 & 0.58 & 0.66 & 0.73 & 0.78 & 0.69 \\
\hline MTU 1010 & 0.57 & 0.62 & 0.68 & 0.73 & 0.65 \\
\hline Anangha & 0.63 & 0.74 & 0.79 & 0.82 & 0.75 \\
\hline Mean & 0.60 & 0.68 & 0.74 & 0.78 & \\
\hline & Main $(\mathrm{V})^{* *}$ & Sub (S) & $\mathrm{V}$ at same $\mathrm{S}$ & S at same V & \\
\hline $\mathrm{SE}+/-$ & 0.01 & 0.01 & 0.00 & 0.02 & \\
\hline $\mathrm{CD}(\mathrm{P}=0.05)$ & 0.03 & 0.03 & NS & NS & \\
\hline \multicolumn{6}{|c|}{60 DAS } \\
\hline RNR 15048 & 2.07 & 2.15 & 2.31 & 2.36 & 2.23 \\
\hline MTU 1010 & 2.09 & 2.19 & 2.32 & 2.43 & 2.26 \\
\hline Anangha & 3.26 & 3.68 & 3.84 & 3.56 & 3.59 \\
\hline Mean & 2.48 & 2.68 & 2.83 & 2.79 & \\
\hline & Main (V) & Sub (S) & $\mathrm{V}$ at same $\mathrm{S}$ & S at same V & \\
\hline $\mathrm{SE}+/-$ & 0.11 & 0.11 & 0.19 & 0.20 & \\
\hline $\mathrm{CD}(\mathrm{P}=0.05)$ & 0.45 & 0.33 & NS & NS & \\
\hline \multicolumn{6}{|c|}{90 DAS } \\
\hline RNR 15048 & 3.79 & 3.91 & 4.03 & 4.09 & 3.96 \\
\hline MTU 1010 & 3.87 & 3.95 & 4.05 & 4.12 & 3.99 \\
\hline Anangha & 3.83 & 3.93 & 4.06 & 4.23 & 4.01 \\
\hline Mean & 3.83 & 3.93 & 4.05 & 4.15 & \\
\hline & Main (V) & Sub (S) & $\mathrm{V}$ at same $\mathrm{S}$ & $\mathrm{S}$ ats same $\mathrm{V}$ & \\
\hline $\mathrm{SE}+/-$ & 0.01 & 0.02 & 0.04 & 0.03 & \\
\hline $\mathrm{CD}(\mathrm{P}=0.05)$ & 0.03 & 0.07 & $\mathrm{NS}$ & NS & \\
\hline \multicolumn{6}{|c|}{ At final harvest } \\
\hline RNR 15048 & 3.69 & 3.74 & 3.84 & 3.95 & 3.81 \\
\hline MTU 1010 & 3.75 & 3.78 & 3.95 & 4.01 & 3.88 \\
\hline Anangha & 3.72 & 3.8 & 3.98 & 4.11 & 3.91 \\
\hline \multirow{2}{*}{ Mean } & 3.74 & 3.78 & 3.93 & 4.03 & \\
\hline & Main (V) & Sub (S) & $\mathrm{V}$ at same $\mathrm{S}$ & S at same v & \\
\hline $\mathrm{SE}+/-$ & 0.01 & 0.03 & 0.06 & 0.05 & \\
\hline $\mathrm{CD}(\mathrm{P}=0.05)$ & 0.02 & 0.10 & NS & NS & \\
\hline
\end{tabular}


Table.4 Effect of different levels of NPK fertigation levels on grain yield (kg ha-1), straw yield, water requirement and water productivity of different varieties of rice at final harvest under aerobic cultivation during kharif 2015

Grain yield $\left(\mathrm{kg} \mathrm{ha}^{-1}\right)$

\begin{tabular}{|c|c|c|c|c|c|}
\hline \multirow[t]{2}{*}{ Varieties } & \multicolumn{4}{|c|}{ Fertigation levels* } & \multirow[t]{2}{*}{ Mean } \\
\hline & $\mathrm{S}_{0}$ & $S_{75}$ & $S_{100}$ & $S_{125}$ & \\
\hline RNR 15048 & 1103 & 1226 & 1504 & 1606 & 1360 \\
\hline MTU 1010 & 1177 & 1376 & 1481 & 1692 & 1432 \\
\hline Anangha & 1382 & 1852 & 2136 & 2578 & 1987 \\
\hline Mean & 1221 & 1485 & 1707 & 1959 & \\
\hline & $\operatorname{Main}(\mathrm{V})^{* *}$ & $\operatorname{Sub}(\mathrm{S})$ & $\mathrm{V}$ at same $\mathrm{S}$ & $\begin{array}{c}\mathrm{S} \text { at } \\
\text { same } \mathrm{V}\end{array}$ & \\
\hline $\mathrm{SE+/-}$ & 59 & 45 & 78 & 90 & \\
\hline $\mathrm{CD}(\mathrm{P}=0.05)$ & 233 & 134 & 163 & 215 & \\
\hline
\end{tabular}

Straw yield $\left(\mathrm{kg} \mathrm{ha}^{-1}\right)$

\begin{tabular}{|c|c|c|c|c|c|}
\hline RNR 15048 & 2508 & 2708 & 3285 & 3682 & 3046 \\
\hline MTU 1010 & 2501 & 2979 & 3311 & 4062 & 3213 \\
\hline Anangha & 3406 & 4404 & 5332 & 6378 & 4880 \\
\hline Mean & 2805 & 3364 & 3976 & 4707 & \\
\hline & Main (V) & Sub (S) & $V$ at same $S$ & $\begin{array}{c}\mathrm{S} \text { at } \\
\text { same } \mathrm{V}\end{array}$ & \\
\hline $\mathrm{SE}+/-$ & 136 & 120 & 181 & 206 & \\
\hline $\mathrm{CD}(\mathrm{P}=0.05)$ & 527 & 309 & 378 & 491 & \\
\hline
\end{tabular}

In conclusion, based on the grain yield and water productivity it can be recommended to go for fertigation of NPK up to $125 \%$ level (150-75-50 kg N-P $2 \mathrm{O}_{5}-\mathrm{K}_{2} \mathrm{O} \mathrm{ha}^{-1}$ ), applied in ten splits at weekly interval to aerobic rice from emergence to flowering stage. Among the varieties tested, Anagha was found to be more suitable for aerobic rice cultivation followed by MTU 1010 and RNR 15048.

Taking in to consideration of economics, it is suggested to eliminate phosphorus from fertigation programme and go for fertigation of only $\mathrm{N}$ and $\mathrm{K}$ up to $125 \%$ through urea and potassium chloride (white) and better to go for soil application of phosphorus fertilizer as single basal dose to make the fertigation programme of aerobic rice as more economically viable.

\section{References}

Lu, J. J and Chang, T.T.1980. Rice production and utilization. AVI Publishing Co. Inc.I

Rakesh, D., Raghu Rami Reddy. P and Latheef Pasha, Md. 2012. Response of aerobic rice to varying fertility levels in relation to iron application. The Journal of Research ANGRAU. 40 (4): 94-97.

Malla Reddy, M., Padmaja. B., Veeranna, $\mathrm{G}$ and Vishnu Vardhan Reddy, D. 2012. Evaluation of popular kharif rice (Oryza sativa L.). varieties under aerobic condition and their response to nitrogen dose.The Journal of Research, ANGRAU. 40 (4): 14-19. 
Ramamoorthy, K, Arokiaraj, A and Balasubramanian, A.1998.Response of upland direct-seeded rice.

De groot, C., Marcellis, L.F.M., Van den Boogoard, R., Lambres, H. 2002. Interactive effects of nitrogen and irradiance on growth and partitioning of dry mass and nitrogen in young tomato plants.Functional Plant Biology 29: 1319-1328.

Abid Khan, S. N., Muhammad Shah, A.B., Muhammad Sajid, K.A and Shah Faisal, A.A. 2014. Influence of nitrogen and potassium levels on growth and yield of chilli (a.) International Journal of Farming and Allied Sciences 3(3):260-264.
Govindan, R and Myrtle Grace, T. 2012. Influence of drip fertigation on growth and yield of rice varieties. Madras Agricultural Journal.99 (46): 244-247.

Kumar, N., Singh, V. K. and Thakur, B. R. 1996.Leaf are index of winter rice as influenced by level and time of nitrogen application. Journal of Applied biology. 5(1/2): 87-88.

Kastura, K and Nakaide, Y.2011. Factors that determine grain weight in rice under high yielding aerobic culture: The importance of husk size. Field crops research. 123: 266-272.

\section{How to cite this article:}

Chandrika, M. Uma Devi, V. Ramulu and Venkata Ramana, M. 2017. Evaluation of Different Varieties of Aerobic Rice (Oryza sativa L.) under Different Fertigation Levels on Growth and Yield Parameters. Int.J.Curr.Microbiol.App.Sci. 6(5): 2793-2801. doi: https://doi.org/10.20546/ijcmas.2017.605.314 